\title{
Unusual presentation of cutaneous Leishmaniasis in pregnancy: A case report
}

\author{
Radia Chakiri', Salim Gallouj', Fatima Zohra Mernissi', Mouna Rimani² \\ ${ }^{1}$ Department of Dermatology, Hassan II University Hospital, Fez, Morocco, ${ }^{2}$ Center of Anatomopathology, Hassan, Rabat, \\ Morocco
}

Corresponding author: Dr. Radia Chakiri, E-mail: r.chakiri.87@gmail.com

\begin{abstract}
Cutaneous Leishmaniasis is a parasitic infection characterized by significant clinical variability. Unusual and atypical clinical aspects of infection have been reported in immunodeficient patients or associated with particular parasite species. We report a pregnant woman with unusual presentation of cutaneous Leishmaniasis.
\end{abstract}

Key words: Leishmaniasis; Skin, Pregnancy

\section{INTRODUCTION}

Worldwide, Leishmaniasis affects 112 million people in 88 countries, with a yearly incidence of 2 million cases [1]. The majority of these cases are cutaneous Leishmaniasis (CL), which is most common in adolescents and young adults from extremely poor rural areas $[2,3]$.

Cutaneous Leishmaniasis (CL) is caused by a parasite from the genus Leishmania infection, and is transmitted to humans by the bite of female sand flies [4].

The clinical features of cutaneous Leishmaniasis (CL) may vary in terms of type and extension, ranging from single, chronic ulcerative lesions to disseminated nodular ones; however, several unusual and atypical clinical features of the disease have been reported in the literature [5-7].

Pregnancy is associated with an altered of human cell-mediated immuneresponse and an increased susceptibility to many infectious agents with atypical cutaneous presentation. Herein, we present a case of a particular clinical aspect of CT on the leg of a pregnant patient. The hypothesis of a possible role of pregnancy in this particular clinical presentation shall be discussed.

\section{CASE REPORT}

A 34-years-old woman, who was five months pregnant, lived in an area endemic for Cutaneous Leishmaniasis in northern Morocco; she was referred to our department because of a painful skin lesion that had been progressing for six months at the front of her right leg.

Dermatological examination showed that Tumoral and cauliflower-like lesion measured $10 \mathrm{~cm}$ long axis, adhered to deep planes and painful on palpation in the centerin the right leg (Fig. 1). It was thought to be Sarcoma, amelanotic melanoma, squamous cell carcinoma. The rest of the physical examination was unremarkable.

Histopathological examination of the biopsy obtained specimens demonstrated ulcerative changes and irregular acanthosis in the epidermis, namely, pseudoepitheliomatous hyperplasia. In dermis infiltration of lymphocyte, plasma cell and histiocyte with multinucleated Giant cell were shown. Leishman bodies were seen in (Fig. 2). With regards to the clinical and histopathological findings, the diagnosis of CL was made.

Complete biological tests were normal and HIV serology was negative for eliminating an immunosuppression.

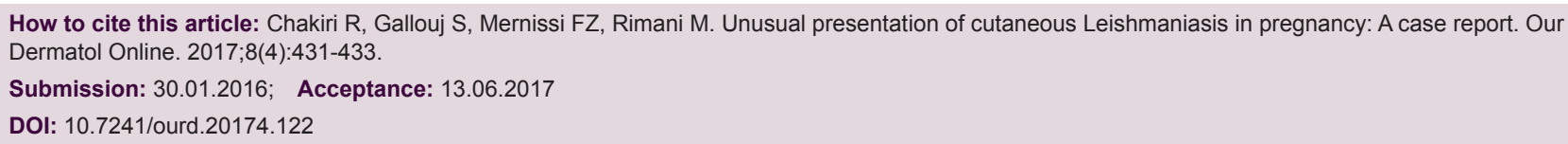




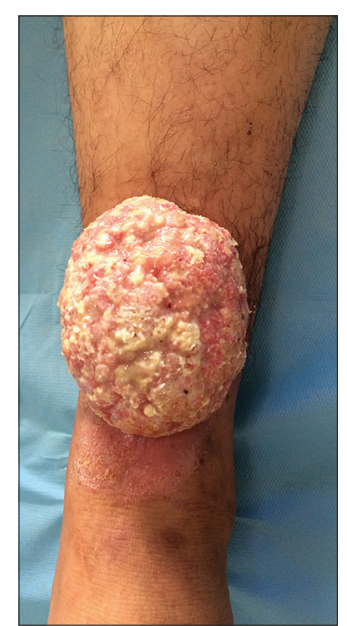

Figure 1: Cauliflower-like lesion of the right leg.

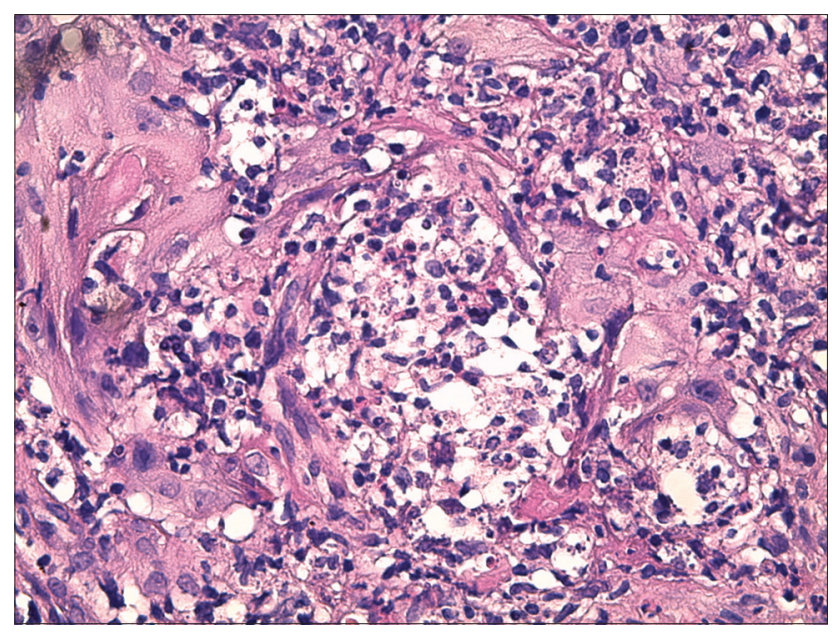

Figure 2: Leishman bodies.

The treatment consisted of surgical excision to relieve the patient because the pentavalent antimony is potentially abortogenic.

\section{DISCUSSION}

The term "Leishmaniasis" defines a group of vectorborne diseases caused by species of the genus Leishmania and characterized by a spectrum of clinical manifestations.

Parasite properties (infectivity, pathogenicity, and virulence), host factors, and host responses regulate heterogeneous disease expression [7].

The most common clinical form is the classical ulcer, with an indurate raised outer border and sharply incised central crater that usually self-heals over a period of months. The usual clinical presentations of Leishmaniasis are easily diagnosed by clinicians in endemic regions, but unusual forms may give rise to difficulties in the diagnosis and appropriate treatments. Cutaneous Leishmaniasis can produce a large variety of atypical and rare forms. There has been an increase in the number of papers reporting unusual clinical presentations, both for the Old and the New World [8-14].

In our Moroccan experience atypical and unusual clinical aspects of LC are observed especially with Leishmaniatropica [15].

This raises the question of the possible involvement of this species in our patient. For technical reasons, we did not perform the identification of the responsible strain.

Another factor that could be responsible for these particular clinical aspects would be pregnancy as in our case.

In contrast to the typical presentation of a welldemarcated ulcer with raised borders, CL during pregnancy is characterized by larger lesions with a highly atypical, exophytic appearance. As in our case, which raised concerns for other diseases, such as tuberculosis, chromomycosis or neoplasms? [3].

In a $\mathrm{C} 57 \mathrm{BL} / 6$ mouse L. major model, larger CL lesions occurred during pregnancy, which correlated with decreased Thl cytokine production [16]. The human cell-mediated immune response is altered during pregnancy [17], with an overcomepensation immediately after delivery.

The study of Conceição-Silva et al showed transient modulation of maternal immune responses during pregnancy as indicated by exacerbated cutaneous lesions, increased parasite burdens, and decreased levels of IFN- $\gamma$ and NOS2 [18].

All hypotheses about the influence of pregnancy on the expression and evolution of CL converge to a possible decrease in the quality of the T-cell response against antigens of leishmaniasis during pregnancy. This immunodeficiency, possibly associated with other factors inherent in the host and parasite, could contribute to a change in the lesion appearance.

Treatment of pregnant CL patients is a debated issue [19-21], since there is no description of congenital infection, and many antileishmanial drugs, such as pentavalent antimony or miltefosine, are teratogenic $[21,22]$. Consequently, alternative therapies 
should be evaluated in order to warrant safety and efficacy in this group of patients. Guimarães et al [23] showed that $40 \%$ of patients with atypical manifestation of CL were pregnant women and suggested that Amphotericin B should be considered as the drug of choice for all patients diagnosed with atypical CL. Intralesional treatment with meglumineantimoniate was successful in over $83 \%$ of patients treated who had contraindication to systemic therapy [24], but there is a lack of evidence demonstrating safety in pregnant women. As spontaneous healing has been reported to occur after delivery [25], several groups avoid the use of specific treatments and follow the patients by using local heating and/or antibiotic ointments to control lesion development and secondary infections. In our case surgery gave good results.

\section{CONCLUSION}

CL during pregnancy is characterized by larger lesions with a highly atypical exophytic appearance. No therapy is known to cure the disease during pregnancy, although postpartum cure has been found to be complete. CL during pregnancy has a notably different clinical presentation. It is important for physicians who are caring for patients in regions where the disease is endemic to recognize this presentation.

\section{REFERENCES}

1. Desjeux P. Leishmaniasis: Current situation and new perspectives. Comp ImmunolMicrobiol Infect Dis. 2004;27:305-18.

2. Jones TC, Johnson WD Jr, Barretto AC, Lago E, Badaro R, Cerf B, et al. Epidemiology of American cutaneous leishmaniasis due to Leishmaniabraziliensisbraziliensis. J Infect Dis.1987;156:73-83.

3. Morgan DJ, Guimaraes LH, Machado PRL, D'Oliveira A, Almeida RP, Lago EL, et al. Cutaneous Leishmaniasis during Pregnancy: Exuberant Lesions and Potential Fetal Complications. Clin Infect Dis. 2007;45:478-82.

4. Mortazavi H, Salehi M, Kamyab K. Reactivation of Cutaneous Leishmaniasis after Renal Transplantation: A Case Report. Case Rep Dermatol Med. 2014;2014:1-3.

5. Grevelink SA, Lerner EA. Leishmaniasis. J Am AcadDermatol. 1996;34:257-72.

6. Calvopina M, Gomez EA, Uezato H, Kato H, Nonaka S, Hashiguchi Y. Atypical clinical variants in new world cutaneous leishmaniasis: Disseminated, erysipeloid and recidivacutis due to Leishmaniapanamensis. Am J Trop Med Hyg. 2005;73:281-4.

7. Bongiorno MR, Pistone G, Aricò M. Unusual clinical variants of cutaneous leishmaniasis in Sicily. Int J Dermatol. 2009;48:286-9.

8. Adriano AL, Leal PA, Breckenfield MP, Costa IS, Almeida C, Sousa AR. American tegumentaryleishmaniasis: An uncommon clinical and histopathological presentation. An Bras Dermatol. 2013;88:260-2.

9. Calpovina M, Gomez EA, Uezato H, Kato H, Nonaka S, Hashiguchi. Atypical clinical variants in New World cutaneous leishmaniasis: Disseminated, erysipeloid and recidivacútis due to Leishmania (V.) panamensis. Am J Trop Med Hyg. 2005;73:281-4.
10. Ceyhan AM, Yildirim M, Basak PY, Akkaya VB, Erturan I. A case of erysipeloid cutaneous leishmaniasis: Atypical and unusual clinical variant. Am J Trop Med Hyg. 2008;78:406-8.

11. Crowe A, Slavin J, Stark D, Aboltins C. A case of imported Leishmaniainfantum cutaneous leishmaniasis; an unusual presentation occurring 19 years after travel. BMC Infect Dis. 2014;14:597.

12. Mings S, Beck JC, Davidson C, Ondo AL, Shanler SD, Berman J. Cutaneous leishmaniasis with boggy induration and simultaneous mucosal disease. Am J Trop Med Hyg. 2009;80:35.

13. Moravvej H, Barzegar M, Nasiri S, Abolhasani E, Mohebali M. Cutaneous leishmaniasis with unusual clinical and histological presentation: Report of four cases. Acta Med Iran. 2013;51:274-8.

14. Sandoval-Juarez A, Minaya-Gómez G, Rojas-Palomino N, Falconi E, Cáceres O. Leishmaniosiscutanea: Manifestaciónclínicainusual. Rev Peru Med ExpSaludPublica. 2014;31:595-7.

15. Chiheb S, Oudrhiri L, Zouhair K, Soussi Abdallaoui M, Riyad M, Benchikhi H. Leishmanioses cutanées d'aspect clinique inhabituel chez trois patients diabétiques. Ann Dermatol Vénéréol. 2012;139:542-5.

16. Krishnan L, Guilbert LJ, Russell AS, Wegmann TG, Mosmann TR, Belosevic M. Pregnancy impairs resistance of C57BL/6 mice to Leishmaniamajor infection and causes decreased antigen-specific IFN-gresponses and increased production of T helper 2 cytokines. J Immunol. 1996;156:644-52.

17. Wegmann TG, Lin H, Guilbert L, Mossmann TR. Bidirectional cytokine interactions in the maternal-fetal relationship: Is successful pregnancy a TH2 phenomenon? Immunol Today. 1993;14:353-5.

18. Conceição-Silva F, Morgado FN, Pimentel MIF, Vasconcellos E de CF e, Schubach AO, Valete-Rosalino CM, et al. Two Women Presenting Worsening Cutaneous Ulcers during Pregnancy: Diagnosis, Immune Response, and Follow-up. McDowell MA, éditeur. PLoSNegl Trop Dis. 2013;7:e2472.

19. Figueiró-Filho EA, Duarte G, El-Beitune P, Quintana SM, Maia TL. Visceral leishmaniasis (kala-azar) and pregnancy. Infect Dis Obstet Gynecol. 2004;12:31-40.

20. Figueiró-Filho EA, El Beitune P, Queiroz GT, Somensi RS, Morais NO, et al. Visceral leishmaniasis and pregnancy: Analysis of cases reported in a central-western region of Brazil. Arch Gynecol Obstet. 2008;278:13-6.

21. Mueller M, Balasegaram M, Koummuki Y, Ritmeijer K, Santana MR, Davidson R. A comparison of liposomal amphotericin B with sodium stibogluconate for the treatment of visceral leishmaniasis in pregnancy in Sudan. J Antimicrob Chemother. 2006;58:811-5.

22. Adam GK, Abdulla MA, Ahmed AA, Adam I. Maternal and perinatal outcomes of visceral leishmaniasis (kala-azar) treated with sodium stibogluconate in eastern Sudan. Int J Gynaecol Obstet. 2009;107:208-10.

23. Guimarães LH, Machado PRL, Lago EL, Morgan DJ, Schriefer A, Bacellar $\mathrm{O}$, et al. Atypical manifestations of tegumentaryleishmaniasis in a transmission area of Leishmaniabraziliensis in the state of Bahia, Brazil. Trans R Soc Trop Med Hyg. 2009;103:712-5.

24. Vasconcellos E de CFE, Pimentel MIF, Schubach A de O, de Oliveira $\mathrm{R}$ de VC, Azeredo-Coutinho RB, Silva F da C, et al. Intralesional meglumineantimoniate for treatment of cutaneous leishmaniasis patients with contraindication to systemic therapy from Rio de Janeiro (2000 to 2006). Am J Trop Med Hyg. 2012;87:257-60.

25. Costa JM, Vale KC, França F, Saldanha AC, da Silva JO, Lago EL, et al. Spontaneous healing of leishmaniasis caused by Leishmania viannia braziliensis in cutaneous lesions. Rev Soc Bras Med Trop. 1990;23:205-8.

Copyright by Radia Chakiri, et al. This is an open access article distributed under the terms of the Creative Commons Attribution License, which permits unrestricted use, distribution, and reproduction in any medium, provided the original author and source are credited.

Source of Support: Nil, Conflict of Interest: None declared. 